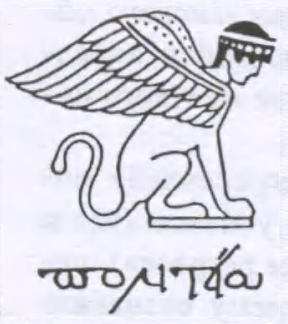

С этого номера "ПО NTTh" начинает публиковать материалы по различным аспектам обозначенной злободневной проблемы.

Часть их - доклады, представленные на конференции, состоявшейся в ИМЭМО РАН в апреле $1999 \mathrm{r}$. (при поддержке

Российского гуманитарного научного фонда, проект

№ 99-03-19875).

'Лeuัnxapm A. Демократия в многосоставных обиествах. М., 1997. C. 38 .

\title{
Г.Г.Дилигенский ГЛОБАЛИЗАЦИЯ: ПЕРСПЕКТИВЫ АЕМОКРАТИИ
}

Проблемы развития и перспектив демократии могут рассматриваться в теоретическом контексте цивилизационной и стадиальной парадигм всемирно-исторического процесса. В первом приближении эти проблемы описываются в виде следующей альтернативы: является ли демократия продуктом исключительно западной цивилизации или необходимым этапом политического развития любого общества на определенном этапе его модернизации? Реальность этой альтернативы подтверждается как проявляющейся в последние десятилетия тенденцией к глобальному распространению демократических институтов, так и трудностями их укоренения и дисфункциональностью в незападных обществах.

Четкость альтернативы значительно ослабевает, если попытаться приложить ее к реальному историческому опыту демократизации. В этом случае становится ясно, что западная цивилизация родилась и развивалась отнюдь не как устойчиво демократическая. В классической античности демократические формы политического устройства сочетались с олигархическими, тираническими и деспотическими и в конце концов уступили место обожествленной и неограниченной монархической власти. Утверждение демократических институтов произошло только на относительно поздней фазе развития западной цивилизации - в эпоху так называемого модерна. Таким образом, демократия, понимаемая как совокупность представительных органов власти, свободных выборов, идейнополитического плюрализма и сменяемости субъектов власти по воле граждан, является стадиальным феноменом в рамках самой этой цивилизации.

Решение сформулированной проблемы значительно затрудняется также размытостью самого понятия «демократия». Фактически оно употребляется в относительном смысле - в контексте диахронных или синхронных сопоставлений различных обществ. Франция времен июльской монархии и современная ей Англия могли считаться демократическими обществами по сравнению с николаевской Россией, но не являются таковыми, если сравнивать их с западноевропейскими странами конца XX в. Иными словами, феномен демократии стадиален еще и в том смысле, что принимает различные конкретные формы на различных фазах своего развития. Очевидно, именно эта его изменчивость побудила одного из наиболее видных современных теоретиков демократии А.Лейпхарта утверждать, что она представляет собой «понятие, решительно не поддающееся определению» ${ }^{1}$. 
Наверное, это все-таки не совсем так. Даже при отсутствии исчерпывающего определения демократии, мы все же хотя бы на интуитивном уровне имеем в виду нечто более или менее определенное: общество, обладающее институтами, позволяющими ему в той или иной степени влиять на власть и политику (хотя это влияние неравномерно распределяется по различным социальным группам и сферам политических решений). В то же время мы имеем в виду общество, предоставляющее, с одной стороны, определенную степень свободы самоопределения личности - выбора формы деятельности, места жительства и работы, убеждений, источников информации и т.п., а с другой - защиту от авторитарного произвола власть имущих, жизнь людей в рамках и под защитой закона. Также в наше понимание демократии мы вольно или невольно включаем, помимо этих общих принципов, и конкретную модель политико-правовой институциональной системы, функционирующую в современном западном обществе.

Адекватность последнего представления вызывает серьезные сомнения. Во-первых, потому, что оно может порождать определенное окостенение, догматизацию понимания демократии, ведущие к искажению исторической перспективы. В свете прошлого опыта вполне можно предположить, что демократия XXI в. будет не меньше отличаться от современной, чем эта последняя от демократических институтов середины XIX в. Во-вторых, при всей приверженности западных обществ своим демократическим порядкам в последнее время в недрах этих обществ возрастает неудовлетворенность достигнутым уровнем и характером функционирования демократии. Как справедливо отмечает французский политолог М.Доган, подробно исследовавший феномен резкого падения доверия к политическим институтам в западных обществах, он свидетельствует не о разочаровании в принципах демократии как таковых, но о стремлении к углублению демократизации, к приведению демократической практики в соответствие с реалиями современной жизни и потребностями

'Dogan M. Confiance aux institutions (Доклад на Всемирном сочиологическом конгрессе в Монреале (1998 2.). Автор имел возможсность ознакомиться с текстом доклада благодаря любезности проф. М.Догана). современного человека ${ }^{2}$.

Это стремление порождается по меньшей мере двумя основными процессами. Один из них - возрастающее значение, которое приобретают в жизни современного общества так называемые технологические решения. Подчиненные целям экономического роста и эффективности, они принимаются бизнесменами и политиками чаще всего вне каких-либо демократических процедур и демократического контроля. Между тем эффект таких решений, как это особенно ясно видно на примере ядерной энергетики или генной инженерии, может быть не менее опасен, чем последствия самых авантюристических решений, относящихся к традиционной политической сфере. Техническая эволюция создает угрозу и самой демократии: новейшие технические средства в руках террористов или феномен хакеров побуждают властные структуры переходить от предотвращения конкретных преступлений к пресечению даже зарождающейся опасности, рассматри-

"ПOАחTh"”" №3 (13) Осень 1999 
${ }^{3}$ Beck U. The Reinvention of Politics. Rethinking Modernity in the Global Social Order. Cambridge, 1997. P. 40-46.

Etzioni A. The Limits of Privacy. N.Y., 1999.

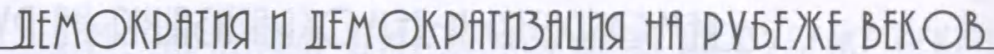

вать каждого гражданина как фактор такой опасности. Отсюда распространение внеправовой практики (тотальная полицейская слежка, прослушивание телефонов и т.п.), нарушающей элементарные права личности.

Другой процесс носит более глубокий, так сказать, антропологический характер. Речь идет об индивидуализации - возрастании индивидуальной автономии, обусловленном прежде всего ослаблением связей индивида с «большим обществом» и его институтами, групповыми субкультурами. Механизмы представительной, парламентской демократии функционируют на основе объединения граждан вокруг групповых культурных традиций, общих интересов, ценностей, политических приоритетов, формулирование и защита которых делегируется партиям и институтам власти. Эта демократия предполагает, что внутри каждого такого объединения и в обществе в целом индивидуальные устремления нивелируются в групповые, подкрепляемые нормами и ценностями соответствующих культур, т.е. меньшинство подчиняется большинству. Индивидуализация, атомизация общества подрывает функционирование этих социально-культурных механизмов представительной демократии. Изначально присущее ей, отмечавшееся еше И.Кантом противоречие между принципом большинства и самоопределением личности обостряется, превращается из имплицитного в эксплицитное.

Анализируя эти проблемы современной демократии, Ульрих Бек, автор получившей известность на Западе книги «Изобретение политики», видит путь к их решению в дедогматизации и десакрализации ее установившихся принципов: демократия, по его мнению, должна превратиться в рефлектирующую. Это означает, что простое воспроизводство ее основ уступает место их критическому анализу и постоянному экспериментированию во всех сферах социального действия ${ }^{3}$. Поиск новых форм демократии становится характерной чертой западной общественной мысли и практики. Он идет прежде всего по линии формирования новых форм социальности, призванных заменить распадающиеся групповые социально-культурные общности более подвижными, временными, флюктуирующими, возникающими на добровольной основе в связи с меняющимися конкретными проблемами и ситуациями. Идет поиск «нового коммюнотаризма», который означает, в числе прочего, по мнению одного из его ведущих теоретиков А.Этциони, ограничение доминирующей роли частного начала («приватности») в жизни индивида и социума ${ }^{+}$. Иными словами, социальность, детерминированная «извне» (групповой принадлежностью, культурной средой и т.д.), заменяется социальностью добровольной, выражающей стремление индивидов, не жертвуя своей автономией, преодолеть взаимную отчужденность на основе поиска общих ценностей и стремлений.

Сегодня трудно сказать, к каким изменениям в демократических институтах может привести этот поиск. По всей видимости, ведущая 
тенденция состоит в повышении роли гражданского общества и его влияния на общество политическое, что, очевидно, требует расширения сферы и обогащения форм его деятельности, распространения ее на уровни решений, являюшиеся сегодня доменом профессиональной политики, технократии и бюрократических структур.

Возвращаясь к интересующей нас проблеме, можно утверждать, что речь идет о новой стадии развития демократии в рамках ее традиционного цивилизационного, т.е. западного ареала. И особенности этой стадии мало что могут сказать о перспективах демократии как всеобще-стадиального, глобально-стадиального феномена.

Здесь мы подходим к проблеме связи демократизации и глобализации и стадиальности демократии в контексте всемирно-исторического процесса. Поскольку ни одна из существующих ныне локальных цивилизаций, кроме западной, не выработала демократических ценностей и институтов (если не считать таковыми первобытные, доцивилизационные отношения), можно полагать, что названная перспектива реальна лишь в случае возникновения новой глобальной цивилизации, которая тем или иным образом внедрит эти ценности и институты в изначально чуждую им среду.

Весьма распространенный оптимистический взгляд на судьбы глобальной демократии фактически основан на представлении, что становление такой цивилизации происходит в результате современного процесса глобализации. В специально посвященном глобализации исследовании института ООН ЮНРИСД отмечается, что распространение либеральной демократии - одна из главных тенденций этого

'Tревоги мира. Социальные последствия глобализачии мировых проуессов. Доклад ЮНРИСД. M., 1997. C. 24,25

"Huntington S.P. Will More Countries Become Democratic? // Political Science Quarterly. 1984. № 99. P. 199

תuncem C.M. и др. Сравнительный анализ условий. необходимых для становления демократии // Международный журнал социальных наук. 1993 № 3. C. 9 . процесса ${ }^{5}$. Вывод основан на том факте, что к середине 1990-х годов институты представительной демократии утвердились во многих еще недавно тоталитарных и авторитарных обществах - в постсоциалистических странах Европы, в ряде стран Латинской Америки, ЮгоВосточной Азии и Южной Африки.

Главным фактором демократизации в условиях глобализации чаще всего считается происходящая под ее влиянием модернизация экономических и социальных структур: развитие на основе современной технологии ведет к росту благосостояния, что открывает дорогу демократии. Как писал в 1984 г. С.Хантингтон, «взаимосвязь между благосостоянием нации и ее демократизацией довольно прочна» ${ }^{6}$. С.М.Липсет, специально исследовавший связь между уровнем экономического развития государства и его политическим строем, считает, что демократизация зависит от многих факторов, но уровень социально-экономического развития является ее «основным и необходимым условием». По его подсчетам, 74\% стран с наиболее низким уровнем экономического развития имеют авторитарный, $24 \%$ полудемократический и только одна страна - Индия - демократический режим. Из стран с уровнем ниже и выше среднего демократическими являются соответственно 11 и 39\%, зато к этой категории относятся все страны с развитой рыночной экономикой․ 
Эти наблюдения представляют несомненный интерес, однако зависимость демократизации от экономического фактора вряд ли является непосредственной. Социально-экономическая предпосылка представительной демократии западного типа (о которой и идет речь в приводимых сопоставлениях) - не рыночная экономика и уровень экономического развития как таковые, но обусловленное ими численное преобладание в социальной структуре так называемого среднего класса. Эту социальную общность объединяет жизненный стандарт, обеспечиваемый благодаря доступности набора основных потребительских благ, поставляемых современным массовым производством, и заинтересованности в социально-политической стабильности, а внутренне разъединяет многообразие конкретных групповых статусов и источников дохода, формируемых рыночными отношениями (частный бизнес, независимый и наемный труд различной квалификации и т.д.). Это сочетание консенсуса и плюрализма интересов превращает средний класс в опору представительной демократии, позволяющей различным его группам выявлять, отстаивать и примирять свои позиции, не нарушая в то же время институциональных основ экономического и социального положения. Если благосостояние основных групп населения обеспечивается не их положением на рынке, а на иной основе, например, как в нефтяных монархиях Персидского залива, благодаря государственному патернализму, плюрализма интересов не возникает, и даже весьма высокий уровень благосостояния не создает социальных предпосылок демократизации. При всех этих оговорках очевидно, что бедные общества, в которых значительные слои населения живут на грани нищеты и маргинализированы в социальном отношении, не представляют собой благоприятной среды для развития демократии.

С точки зрения социально-экономического фактора перспективы глобальной демократизации выглядят вовсе не столь оптимистично, как это кажется многим авторам. Хорошо известно, что нынешний этап глобализации сопровождается увеличением разрыва в экономическом положении между наиболее развитыми и большинством остальных стран. Если эта тенденция сохранится, не следует ожидать быстрого и равномерного экономического и социального прогресса развивающихся обществ, радикального повышения жизненного уровня их населения и, следовательно, формирования социальных предпосылок «работающей» представительной демократии. Во многих из тех стран, где под влиянием кризиса тоталитарных и авторитарных режимов и притягательности «западной модели» за последние десятилетия были созданы формально-демократические институты, они остаются неустойчивывми, часто дисфункциональными и выступают как дополнительный фактор социальной и политической нестабильности.

Серьезным препятствием глобальной демократизации, во всяком случае в соответствии с пока не имеющей ясных альтернатив западной моделью, является культурная самобытность незападных обществ, которую не в состоянии нивелировать никакая вестернизация. Так, в 


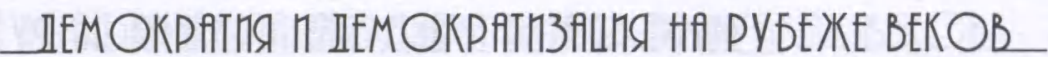

культурном контексте афро-азиатских обществ ценность индивида, личности, основополагающая для западной культуры и образующая важнейшую духовную предпосылку демократизации, воспринимается как чужеродный элемент. И хотя процесс индивидуализации происходит и в этих обществах, он все же еще мало влияет на присущее им растворение индивидуального в групповом. Во многих странах это групповое начало - самоидентификация граждан не с государствомнацией, а с этническими и религиозными группами - делает невозможной реализацию принципа большинства, лежащего в основе представительной демократии. Все это не обязательно исключает демократизацию, но делает ее малоэффективной в тех формах, которые выработаны западным обществом. К тому же в некоторых культуpax, например в исламской, заложена традиция слияния светской и религиозной, авторитарной по своей природе, власти.

Перспективу глобальной демократизации значительно отдаляет и сложившаяся структура международных отношений, ее влияние на процесс глобализации. В XIX - первой половине XX в. демократизация западных обществ сочеталась с агрессивно-имперской, колонизаторской политикой на мировой арене. Деколонизация середины XX в., разумеется, изменила ситуацию, но не привела к радикальной демократизации международных экономических и политических отношений. После распада мировой социалистической системы Запад почувствовал себя хозяином на планете, интересы и мощь стран «золотого миллиарда», прежде всего США, во многом определяют ход и результаты процесса глобализации. События вокруг Югославии показали готовность Запада вмешиваться силовыми методами в решение внутриполитических проблем других стран. Однако демократию невозможно импортировать антидемократическими, тем более военными способами - такая линия поведения может привести лишь к усилению национализма и питаемого им авторитаризма, дискредитировать западную модель демократии.

Сказанное свидетельствует об асимметричности процессов демократизации в различных регионах мира. Если западные общества решают проблему преодоления дисфункций представительной демократии приведением демократических институтов в соответствие с реалиями постиндустриальной эпохи, то обществам Юга и Востока предстоит труднейший процесс выработки и «освоения» адекватной их условиям и традициям демократической практики, стабильного демократического порядка. Теоретически возможны различные «сценарии будущего»: принципиально новые фазы демократического процесса в одних регионах и его стагнация в других; «встреча» и взаимное обогащение различных его потоков. Наименее вероятной в обозримом будущем представляется унификация и нивелирование форм этого процесса в различных цивилизационных ареалах: если в мире и сложится глобальная демократическая цивилизация, она скорее всего не будет внутренне единообразной, «подстриженной под одну гребенку». 